11) 岡村, 東村, 藤井：高化, 15, 431 (1958)

12) 岡村, 東村：J. Polym. Sci., 21，289(1956)

\title{
Cationic Polymerization of Vinyl Phenyl Ether
}

\section{Reactivity of Vinyl Phenyl Ether}

By Seizo Okamura, Toshinobu Higashimura and Kiyoshi Fujii

For the cationic homo-polymerization, vinyl phenyl ether is more reactive than styrene, and so only vinyl phenyl ether polymerizes at initial stage of the copolymerization with styrene catalyzed by stannic chloride and thereafter inhibits the copolymerization of styrene. But in the case of radical polymerization, vinyl phenyl ether decreases both the rate of the reaction and the degree of the polymerization of polystyrene. The reaction kinetics are found to be able to summarize by the followings;

$$
\begin{aligned}
& R_{0}=k\left[\mathrm{SnCl}_{4}\right]^{2}[M]_{0} \\
& R_{0}=k\left[\mathrm{BF}_{8} \cdot \mathrm{O}\left(\mathrm{C}_{2} \mathrm{H}_{3}\right)_{2}\right][M]_{0}
\end{aligned}
$$

第 2 報 四塩化スズを触媒とする重合の特異性

(1957 年 12 月 28 日受理)

岡村誠三・東村敏延・滕井洌

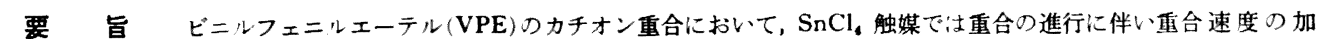
速が認められるが、これは反底系こジエチルエーテルを添加しても，重合温度を低下しても依然として認められる。重合終了 采にモノマーを添加して重合させるところつ“悢り返し重合”を行うことにより加速を消失せしめることができた。 $\mathrm{SnCl}_{4} の$

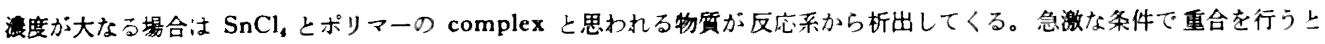

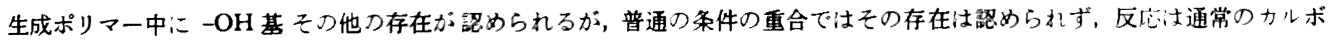
ニウムイオン機で進行すると思われる。

\section{1. 緒言}

前報)においてビニルフェニルエーテル(VPE)のカチオン重合を行う場合, $\mathrm{BF}_{3} \cdot \mathrm{O}\left(\mathrm{C}_{2} \mathrm{H}_{5}\right)_{2}$ と買なり $\mathrm{SnCl}_{4}$ を触媒とする場合は反応が進行すにつれて重合速度が增大するという異常な現象が㤎められた。この

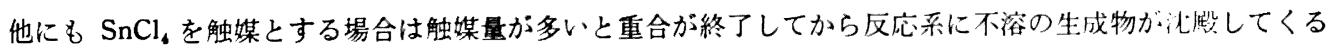
などの特異な現象が見られる。本報告ではこれらの異常な举動を確踗し，さらに生成ポリマーの構造を研究 し，それらの結果に基いて $\mathrm{SnCl}_{4}$ 触媒による重合機構を解明せんとするものである。

\section{2. 㝜匬}

実験操作および試料の精彆はすべて前報”と同様に行った。

\section{3. 結果}

\section{I. $\mathrm{SnCl}_{4} に よ る$ 合の加速について}

重合の進行に伴う加速について重合条件とその加速の程度の関係を求め,それより加速の原因を明らかに するため次の実験を行った。 


\section{(1) 低温ての重合}

前報で加速の原因は重合熱の蓄積によるものでない ことを述へたが，さらに低温で重合した場合はどうな るかの点を明確にするため, 二塩化エタンを溶媒とし て $-20^{\circ} \mathrm{C}$ で重合を行った。低温での重行の進行を連 続的にみるために $\mathrm{Hg}$ が反応に影響がないと考え，メ ニスカス降下を $\mathrm{Hg}$ より見る Burnett ${ }^{2)}$ により報告さ れたものの改良型のディラトメーターを用いた。結果 は第1図に示すように $-20^{\circ} \mathrm{C}$ の低温でも重合後期の 加速は依然として認められた。

(2) ジエチルエーテルの存在下ての重合

加速は $\mathrm{SnCl}_{4}$ のみにみられ $\mathrm{BF}_{8} \cdot \mathrm{O}\left(\mathrm{C}_{2} \mathrm{H}_{5}\right)_{2}$ に認め られない。この点を考慮してジェチルェーテルの添加

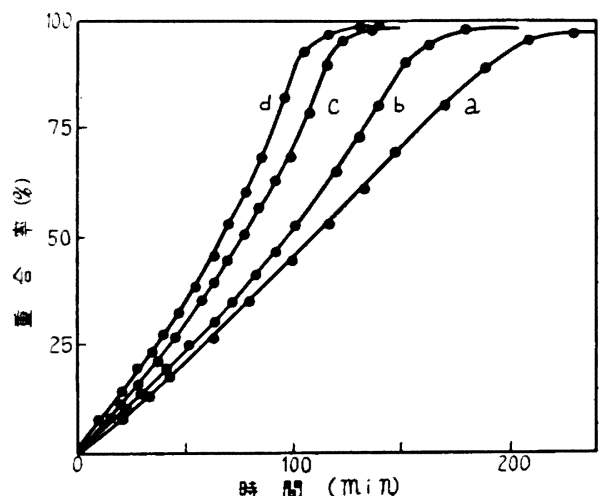

$[\mathrm{VPE}]_{0}: 1.61 \mathrm{~mol} / l, \quad\left[\mathrm{SnCl}_{4}\right]: 5.53 \times 10^{-8} \mathrm{~mol} / l$ ベンゼン溶媒 $30^{\circ} \mathrm{C},\left[\left(\mathrm{C}_{2} \mathrm{H}_{5}\right)_{2} \mathrm{O}\right] /\left[\mathrm{SnCl}_{4}\right]$, a: 0 , $\mathrm{b}: 1.0, \mathrm{c}: 4.0, \mathrm{~d}: 10.0$

第2 図VPEの重合に及ぼすジェチル エーテル添加の影響

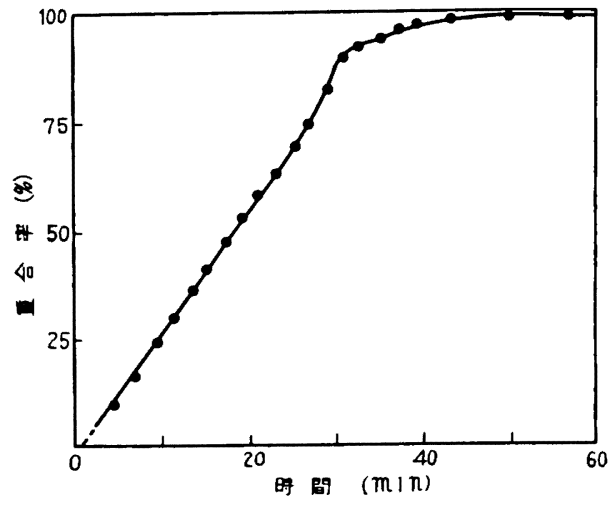

$[\mathrm{VPE}]_{0}: 1.6 \mathrm{~mol} / l,\left[\mathrm{SnCl}_{4}\right]: 9.55 \times 10^{-3} \mathrm{~mol} / l$, 二塩化エタン溶媒 $-20^{\circ} \mathrm{C}$ 重合

第 1 図 $\mathrm{SnCl}_{4}$ による $\mathrm{VPE}$ の低温重合

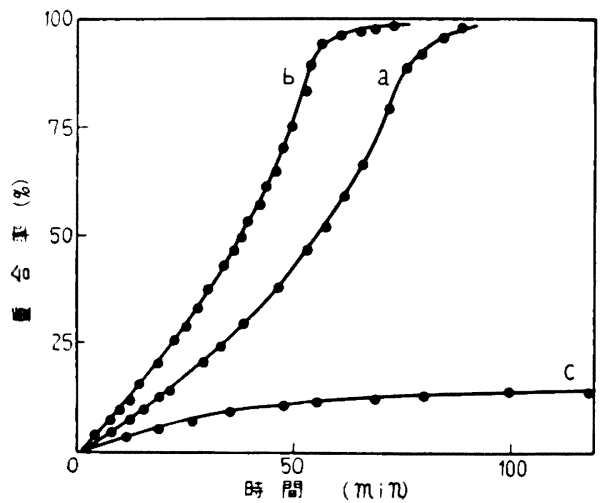

$[\mathrm{VPE}]_{0}: 1.61 \mathrm{~mol} / l,\left[\mathrm{SnCl}_{4}\right]: 7.0 \times 10^{-8} \mathrm{~mol} / l$, ヘンゼン溶媒 $30^{\circ} \mathrm{C}, \quad[\mathrm{PhOH}] /\left[\mathrm{SnCl}_{4}\right]$, a : 0 , b : $1.0, \mathrm{c}: 10.0$

第 3 図VPE の重合に及ぼすフェノール 添加の影響

の影響を検討した。結果は第 2 図に見られるように変化はなく，少量のエーテルの添加は重合速度を増加 する。

\section{(3) フェノールの存在下ての重合}

後述するように重合中にフェノールが生成する可能性がある。したがって重合がこの副生するフェノール で加速されるかも知れない。それゆえフェノールの添加の影響を検討した。第3図から明らかなよらに少量 のフェノール ([PhOH]/[ $\left.\left[\mathrm{SnCl}_{4}\right]=1.0\right)$ は重合速度を增加せしめるが過剩のフェノール $\left([\mathrm{PhOH}] /\left[\mathrm{SnCl}_{4}\right]=\right.$ 10.0) は逆に重合速度を低下せしめ，重合は完全に進行することなく重合率 $60 \%$ 付近で重合は停止した。実 䮖例は少ないがこの結果からではフェノールの副生があったとしてもその加速の程度は実験でみられるよう に大きなものでなく，また重行の進行に伴い多量のフェノールが副生する可能性も少ないよらに思われる。 


\section{(4) 同一重合系における“繰り返し重合”}

われわれはスチレン-SnCl 4 -ベンゼン系で1 度重合の終了した系化びモノマーを加えると, 重合禁止期な しに重合が進行することを報告した ${ }^{8)}$ 。これと同様に $\mathrm{VPE}-\mathrm{SnCl}_{4}$ 系で種々の溶媒中で重合を行い，重合完 了後反応系に再びモノマーを補給する操作を繰り返し反応速度を測定した。モノマーを繰り返し添加するこ とにより系の透電定数および触媒濃度が変化する。透 電定数の影響を吟味するために種々の溶媒中で実験を 行ったが，重合初速度の大小を除いて曲線の形は溶媒 の種類(二塩化エタン, エチルブロマイド,クロロホル ムおよびベンゼン)によらず同じ変化を示した。今透 電定数の変化が比較的少ないと考えられるクロロホル ム中の重合結果を第 4 図に示す。ここではクロロホル ム $90 \mathrm{cc}$ とモノマー $10 \mathrm{cc}$ の采で $\mathrm{SnCl}_{4}$ 濃度 $9.15 \times$ $10^{-3} \mathrm{~mol} / l$ で重合を行い, 反応が終了すると反応液 $90 \mathrm{cc}$ にさらにモノマー $10 \mathrm{cc}$ を加える。この操作を 2 回繰り返して行った。したがって触媒浿度はこれに 伴い10\%。ずつ減少することになる。第4図に見られ るように, 最初の重合曲線 $\mathrm{a}$ は通常の場合上同様加速

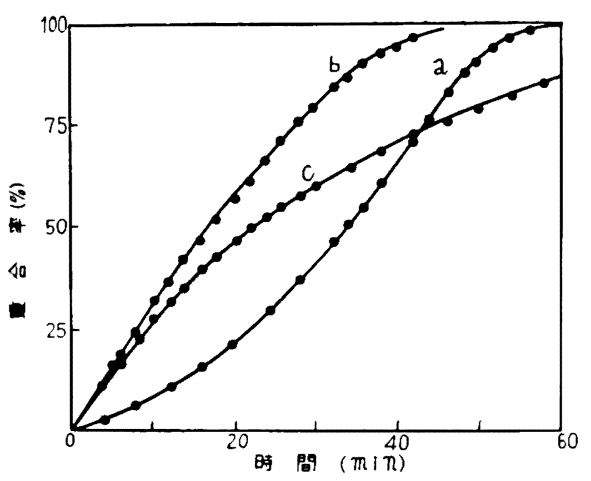

$[\mathrm{VPE}]_{0}: 0.81 \mathrm{~mol} / l, 30^{\circ} \mathrm{C}$

$\left[\mathrm{SnCl}_{4}\right]:$ a : $9.15 \times 10^{-8} \mathrm{~mol} / l$, b : $8.23 \times 10^{-3}$, c : $7.41 \times 10^{-3}$

第 4 図クロロホルム中における VPE の繰り返し重合 しているが, 第 2 図の重合曲線bは触媒瀑度が a の $90 \%$ に減少しているにもかかわらず重合初速度は第 1 図の重合より増加している。そして重合後期の加速はその程度が減じている。第 3 図の重合曲線 $\mathrm{c} て ゙ は$ 加速 は全く認められず, 重合初速度もbより小となっている。これらの重合を通じて生成ポリマーの分子量はモ ノマーの添加により增加する傾向を示す。

\section{II. 重合終了後の生成ボリマーと $\mathrm{SnCl}_{4}$ の作用について}

\section{(1) ポリマーと $\mathrm{SnCl}_{4}$ の complex}

ペンゼンを溶媒として重合を行ら場合 VPE の初謈度 $[M]_{0}$ を小とし $[M]_{0}$ と $\mathrm{SnCl}_{4}$ の初濃度 $[C]_{0}$ の比 $[M]_{0} /[C]_{0}$ が約 100 上り大となると，重合の終了した反応液を放置しておくと,ベンゼンおよびアセトンに不

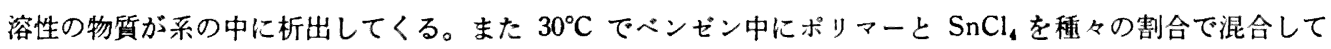
放置すると，第 1 表に見られるよ5に重合後反応液を放圆した場合と同様沈殿を生じ,ポリマー濃度をモノマ 一単位で示すと $[M] /[C]$ が 100 を越すと沈皘を生しなくなる。この生成物をぶンゼンで十分洗浄した後 $60^{\circ} \mathrm{C}$,

第 1 表 ポリマーと $\mathrm{SnCl}_{4}$ の 相互作用 溶媒: ベンゼン, $30^{\circ} \mathrm{C}$ 放置

\begin{tabular}{|c|c|c|c|c|}
\hline 番 & $\underset{\left(\mathrm{mol}_{1} / l\right)}{\left[\mathrm{SnCl}_{4}\right]}$ & 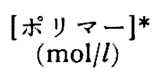 & 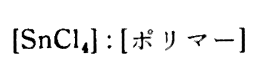 & 沈殿生成の有無 \\
\hline A & $1.13 \times 10^{-3}$ & 0.226 & $1: 200$ & なし \\
\hline B & $1.13 \times 10^{-3}$ & 0.113 & $1: 100$ & なし \\
\hline $\mathrm{C}$ & $4.96 \times 10^{-3}$ & 0.124 & $1: 25$ & 沈殿 \\
\hline D & $23.24 \times 10^{-3}$ & 0.030 & $1: 1.3$ & 沈殿 \\
\hline
\end{tabular}

*使用ポリマーの分子量は 1350 であり，湌度はモノマー単位で示した。 
$5 \mathrm{mmHg}$ で減圧乾燥したものを元素分析し た。比較のためここで使用したポリマーの分 析值をあわせて第 2 表に示した。使用したポ リマーの組成は理論値 (H: $6.7 \%$, C : 80.0\% ) とよく一致している。触媒分子とポリマー分 子の結合している割合を C:P で示すと, ポ リマーの分子量 1350 の場合 complex 中の 炭素含有率と C : P の関倸は次に示すようになる。したがって第 2 表の結果より試料 C では C: P はほぼ $1: 1.5$, 試料Dでは $2: 1$ に近いものと思われる。

$\begin{array}{ll}\mathrm{C}: \mathrm{P} & \mathrm{C}(\%) \\ 2: 1 & 59.1 \\ 1: 1 & 67.1 \\ 1: 2 & 73.0\end{array}$

ベンゼン溶液中で生じた complex は外気に触れさせることなくそのままの状態では,その程度は弱いけれ どもスチレンを重合せしめる。この沈殿生成物にスチレンモノマーを添加すると徐々に重合し, 重合の進行 に伴い汢殿生成物はしだいに溶解して遂には消失する。したがって両者の間に強い化学的な結合があると考 えがたい。

\section{(2) 高温てのホリマーの反応}

ベンゼン溶液中の重合で $\mathrm{SnCl}$ をを大量に加えて激しく重合せしめると, 反応液は著しいフェノール奥を示 し, $\mathrm{FeCl}_{3}$ によるフェノールの呈色反応を示す。また $\mathrm{SnCl}_{4}$ の存在でポリマーを高温で加熱すると同様の現 象を示した。

$30^{\circ} \mathrm{C}$ でベンゼン溶液中にて $[M]_{0}: 1.61 \mathrm{~mol} / l,\left[\mathrm{SnCl}_{4}\right]: 7.35 \times 10^{-3} \mathrm{~mol} / l$ の比較的ゆるやかな条件で重合 を行い, 反応物をメタノールに投入してロ液を井本氏らいの報告と同様に $50^{\circ} \mathrm{C}$ まで加熱して減圧で分留した。 米之応モノマーを留出せしめた残部は $\mathrm{FeCl}_{3}$ による呈色反応を示さなかった。しかしこれを水の共存で数十 分煮沸すると呈色反応を示す。また反応液を少量のメタノールに投じ， $120^{\circ} \mathrm{C}$ まで加熱すると著しい呈色反 応を示した。以上の定性的な実験からではあるが，激しい反応条件では井本氏らの結果を同様に，重合中で も重合終了後でもポリマーよりフェノールが脱離することが考えられる。しかしゆるやかなる条件下ではフ エノールの生成は非常に少ないかあるいはほとんどないものと思われる。

\section{III. 生成ボリマーの搆造について}

前報で述べたように aryl vinyl ether が転位を起すことが報告されているので, $\mathrm{SnCl}$ 、触媒での重合条件 と生成ポリマーの構造の関倸を検討するため生成ポリマーの赤外線吸収スペクトルを求めた。結果は第 5 図 に示すとおりで, 曲線 a は普通の条件でゆるやかに重合し， $\mathrm{NH}_{4} \mathrm{OH}$ 性メタノールで反応を停止して得たポ

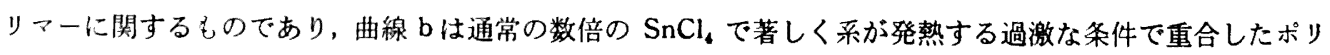
マーを同様の方法で反応を停止し,ともにできるだけ精製を行ったものを $\mathrm{CCl}$ 、溶液とし, Perkin-Elmer 21 型で得たものである。ポリマーの詳練な構造と反応機構については別に述べる予定であるのでここでは主と して曲線 a とbの差について議㖮する。 


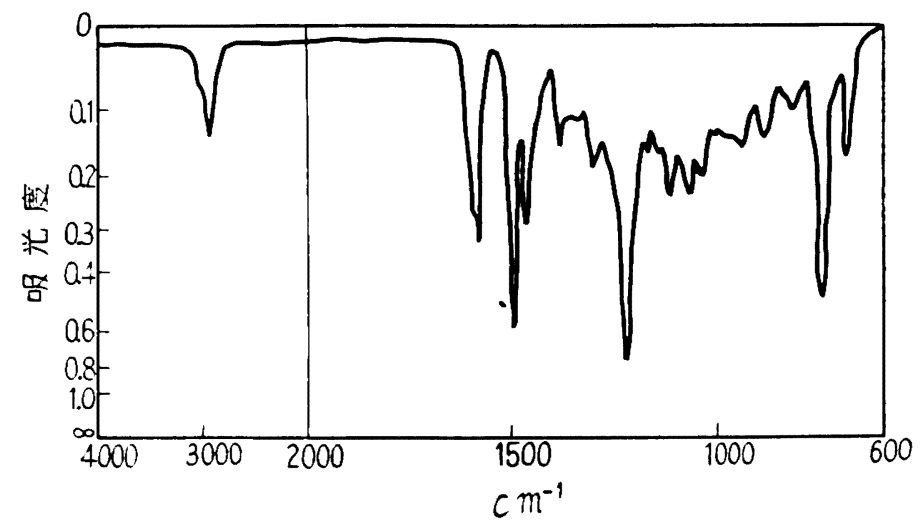

(a)

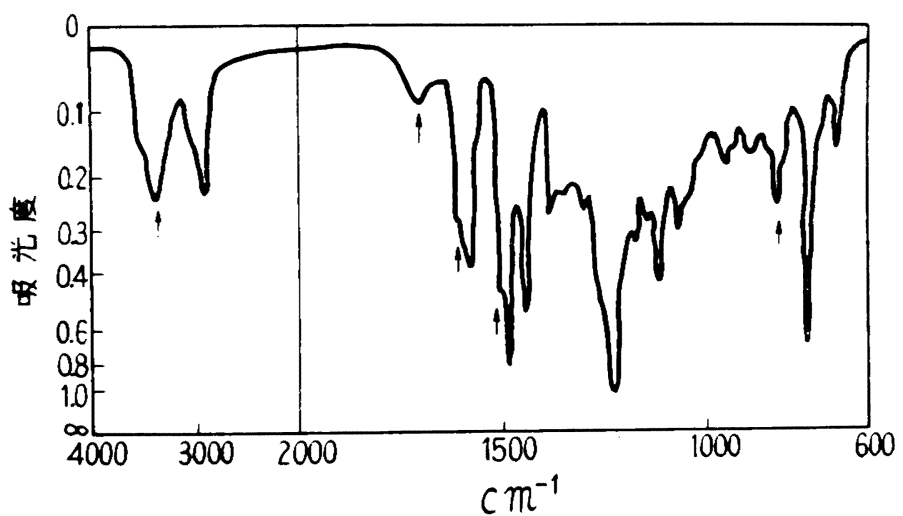

(b)

$\mathrm{a} ：$ ゆるやかな条件で得たポリマー, b：過激な条件で得たポリマー

第 5 図 生成ポリマーの赤外吸収スペクトル

\section{(1) $-\mathrm{CH}_{8}$ 基の存在}

曲線 $\mathrm{a}$ および b の共通の問題として注意すべきことは,ともに $-\mathrm{CH}_{8}$ 基による吸収 $\left(2970\right.$ および $2890 \mathrm{~cm}^{-1}$ (C-H streching)：1457 および $1382 \mathrm{~cm}^{-1}$ (C-H deformation) が明眿に示されているのに対し， C=C 結合 による $1640 \mathrm{~cm}^{-1}$ 付近の吸収が認められず, $850-1000 \mathrm{~cm}^{-1}$ の吸収もあまり明瞭でないことである ${ }^{5), 日) 。 こ ~}$ のことは重合機構に対して重要な示哮を与えるものである。

\section{(2) 曲線 $\mathbf{a}$ およひ b の比較}

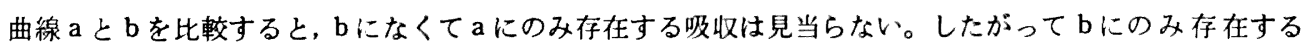
吸収を議論する。

$3390 \mathrm{~cm}^{-1}$ 付近の幅の広い吸収は, 明瞭に $-\mathrm{OH}$ 基の存在を示しているが,これは単独の $-\mathrm{OH}$ 基の吸収 $\left(3600 \mathrm{~cm}^{-1}\right)$ よりずれており, 分子間または分子内の水素結合の存在を示すものと考えられる5)。一方 830 , 1510 および $1610 \mathrm{~cm}^{-1}$ に現われる吸収は, 今の場合ベンゼン核の 1, 2, 4-3 㯰換体の存在は考えがたいから， これは明らかにベンゼン核の para-2 置換体の吸収を示すものと考えられる゙，7)。ゆえに $-\mathrm{OH}$ 基がフェニル 基の para-位置に転位したことを示しているものと思われる。

$1710 \mathrm{~cm}^{-1}$ 付近の吸収は $\mathrm{C}=\mathrm{O}$ 基によるものと考えられる ${ }^{5}$ 。したがってこのような過激な条件では $\mathrm{OH}$ 基 
の転位, フェノールの発生とともにポリマー中にカルボニル基も少量生ずるらしい。もちろんこれらの吸収 はモノマーには存在しない昂。

\section{4. 考察}

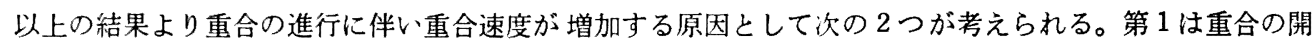
始に触媒とモノマーとよりなる活性中心が必要で，その生成に時間を要するか，または系の中の不純物が消 費されるまで活性中心が生じないとする考え方である゙す。スチレンではモノマーの活性中心の反応性が小さ いので重合禁止期が現われるが，VPEでは反応性が大きいので徐々に重合するのであろう。したがってスチ レンの場合と同様くり返してモ, ーを加えると触媒濃度は全体として減少するが, 有効な活性中心はすで に存在しているので最初から早い速度で反応が進行し，それ以上加速することなしにモノマー濃度の減少と ともに速度を减少しながら重合が進行するものと思われる。

第 2 は反応中副生するフェノールその他の物質で加速が起るとする考え方である。すでに述べたように $\mathrm{SnCl}_{4}$ とポリマーの complex は重合を加速すると考えられず, むしろ反応を遅らせるものと思われる。一方 第3 図より見られるように少量のフェノールは重合を促進するが，多量のフェノールは重合を抑制する。し たがって最初 $\mathrm{SnCl}$ 、により重合が進行するにつれて少量のフェノールが副生し，それが共触媒となって重合 が促進される。くり返して重合を行う場合はそれ以後生成するフェノールは抑制作用をして加速を起さしめ ないとする説明である。しかし重合中の加速はフェノールの添加によって生ずる初速度の增加に比して著し く大きいこと, および触媒濃度とモノマー濃度に関係なくこの現象がみられることは, 第 2 の説明では解䣋 しがたい。第 4 図より一応この2つの原因が考えられ，第1の考えが主原因でないかと思われるが，その決 定はこれだけの結果では困難である。

ベンゼン中で $\mathrm{SnCl}$ 、によりゆるやかな条件で重合した場合, 過激な条件で重合した場合の生成ポリマーと 異なり，第 5 図に見られるよ5に $\mathrm{OH}$ 基による吸収は認められない。この結果は井本氏ら“の結果と矛盾し ているが，一般にカチオン重合では溶媒が異なると反応機構の異なることも考えられ，特に四塩化炭素中の 重合ではその可能性も多い。この結果と $-\mathrm{CH}_{\mathrm{s}}$ 基 がポリマー中に存在することより, $\mathrm{VPE}-\mathrm{SnCl}_{4}$ ベンゼン 系では活性化の段階は次式のようにモノマーへのプロトン付加であり, 通常のカルボニウムイオンによるビ<smiles>C[C]([CH+]C=Cc1ccccc1)Oc1ccccc1</smiles>

ニル重合と考えられる。そして重合度が小さいのは移動反忘が起りやすいためであろう。ただ生成ポリマー 中に二重結合の存在が明瞭でないが、これより移動および停止の形を決定することは困難である。そして反 応条件が激しい場合副反応を起し，パラ位直への $\mathrm{OH}$ 基の転位，カルボニル基の生成およびフェノールの副 生を伴うのであろう。

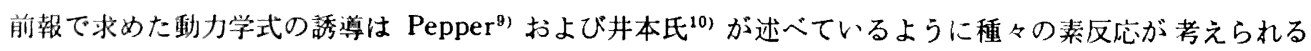
が，倧止反応機構が明瞭でないので一義的な決定ができない。この点については $\mathrm{BF}_{3} \cdot \mathrm{O}\left(\mathrm{C}_{2} \mathrm{H}_{5}\right)_{2}$ 触媒の場合 とともにさらに生成ポリマーの構造を詳細に検討する必要があり後報に述べる。

付 記：本報告は㒖分子学会第 5 年会 (1956 年 5 月) で発表した。最後に赤外吸収スペクトルの結果についご教示 をいただいた京都大学の竹中亨氏，および実験に協力いただいた三菱化成に感期する。 


\section{文献}

1) 岡村, 東村, 藤井：高化, 15, 425(1958)

2) G.M. Burnett: “Mechanism of Polymer Reaction.” Interscience, New York, 15(1954)

3) 岡村, 東村：J. Polym. Sci., 21, 289 (1956)

4) 井本, 竹中：高化, 13, 268(1956)

5) L. J. Bellamy: "The Infrared Spectra of Complex Molecules" John Wiley and Sons, New York (1954)

6) F. M. Rugg, J. J. Smith and L. H. Wartman: J. Polym. Sci., 11, 1(1953)

7) H.W. Thompson: J. Chem. Soc., 1948, 328

8) Y. Mikawa: Bull. Chem. Soc., Japan, 29, 110(1956)

9) D.C. Pepper: Quart. Rev., 8, 88(1954)

10) 井本：高化, 13，295(1956)

\section{Cationic Polymerization of Vinyl Phenyl Ether \\ II. The Characteristics of Cationic Polymerization Catalyzed by Stannic Chloride}

By Seizo Okamura*, Toshinobu Higashimura* and Kiyoshi Fujii*

The rates of polymerization are found to increase as reaction proceeds. Although this phenomena of rate-acceleration are recognized to occur even at low temperature, the procedure of repeated polymerization, e.g. the method of polymerizing monomer in presence of the poly. merized mixture, can diminish this accelerating phenomena. The polymer produced in the case of very fast reaction contains some amount of $\mathrm{OH}$-groups but the polymer obtained at the normal condition is not the case. The polymerization in this report may be explained by the usual carbonium ion mechanism.

* Department of Textile-Chemistry, Faculty of Engineering, Kyoto University (Kyoto) 